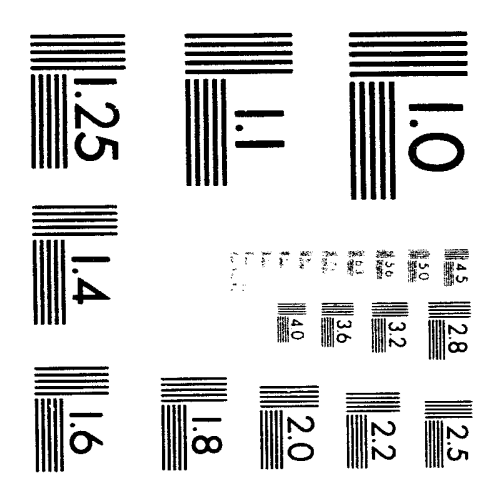



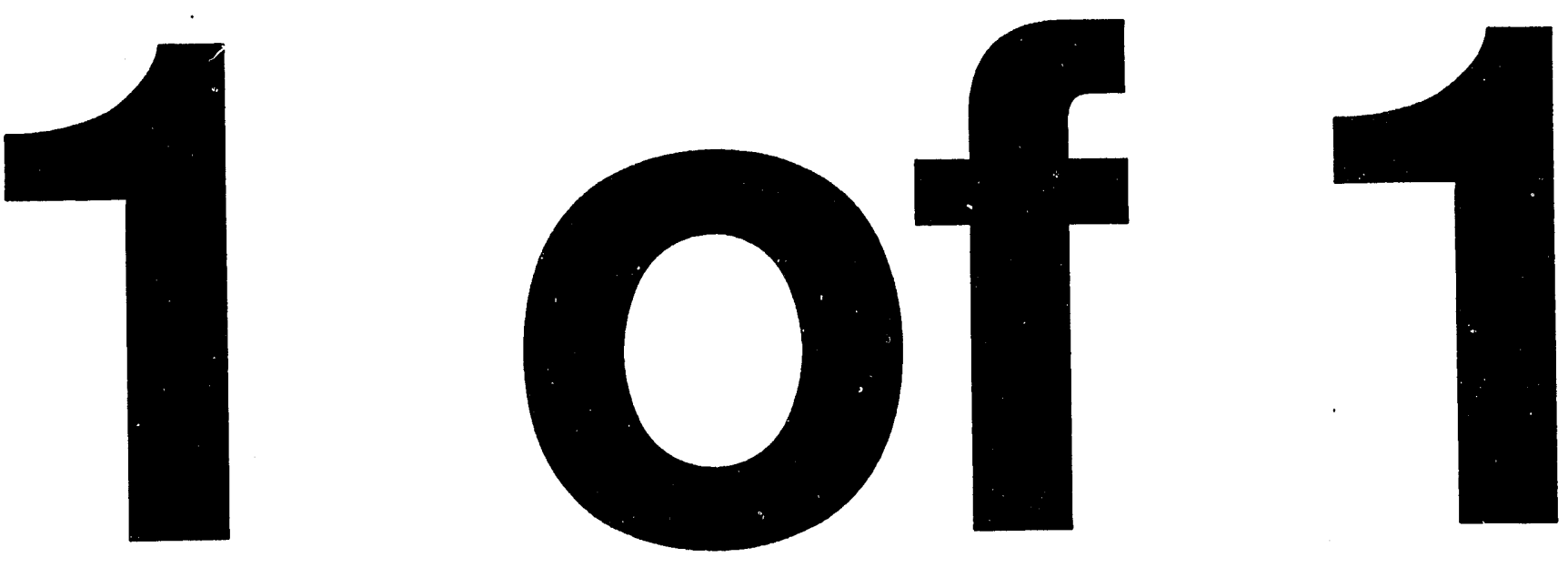
ARGONNE NATIONAL LABORATORY

9700 South Cass Avenue, Argonne, Illinois 60439

\section{Preliminary Assessment Report for \\ Kent National Guard Facility \\ (Installation 53065), 24410 Military Road, Kent, Washington}

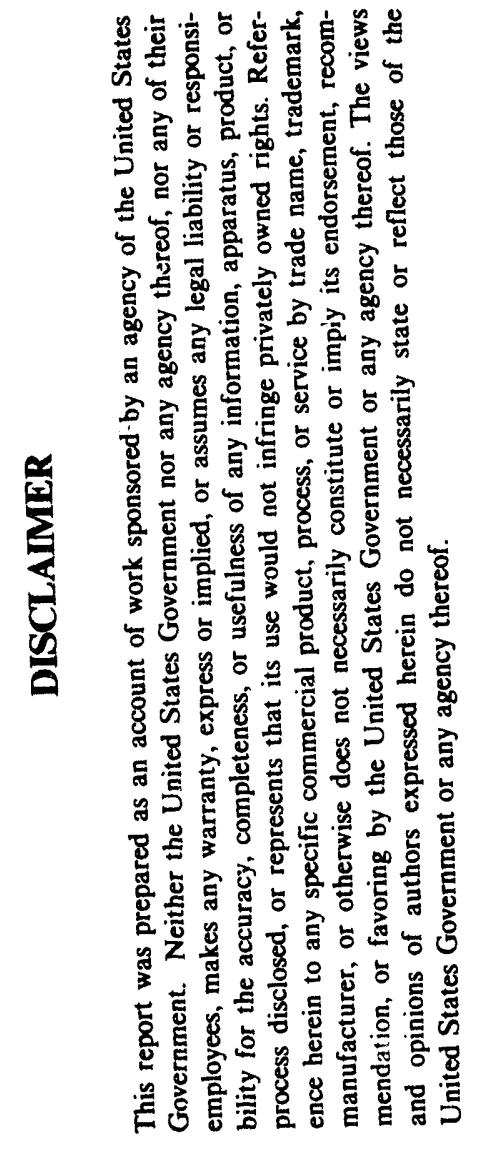

Prepared for

National Guard Bureau, Army Directorate

Aberdeen, Maryland

August 1993

Prepared by

Applied Geosciences and Environmental Management Section

Environmental Research Division

Argonne National Laboratory 


\begin{tabular}{|c|c|c|c|}
\hline \multicolumn{2}{|c|}{ REPORT DOCUMENTATION PAGE } & \multicolumn{2}{|c|}{$\begin{array}{l}\text { FORM APPROVED } \\
\text { OMB No. } 0704-0188\end{array}$} \\
\hline \multicolumn{4}{|c|}{$\begin{array}{l}\text { Public reporting burden for this collection of information is estimated to average } 1 \text { hour per response, including } \\
\text { the time for reviewing instructions, searching existing data sources, gathering and maintaining the data needed, } \\
\text { and completing and reviewing the collection of information. Send comments regarding this burden estimate or } \\
\text { any other aspect of this collection of information, including suggestions for reducing this burden to Washington } \\
\text { Headquarters Services, Directorate for Information Operations and Reports, } 1215 \text { Jefferson Davis Highway, } \\
\text { Suite } 1204 \text {, Arlington, VA } 22202.4302 \text { and to the Office of Management and Budget, Paperwork Reduction } \\
\text { Project (0704-01880), Washington, DC } 20503 \text {. }\end{array}$} \\
\hline $\begin{array}{l}\text { 1. AGENCY USE ONLY } \\
\text { (Leave Blank) }\end{array}$ & $\begin{array}{l}\text { 2. REPORT DATE } \\
\text { August } 1993 \\
\end{array}$ & $\begin{array}{l}\text { 3. REPORT TYPE AND } \\
\text { Preliminary site visit to }\end{array}$ & $\begin{array}{l}\text { ATES COVERED } \\
\text { complete assessment. }\end{array}$ \\
\hline \multicolumn{3}{|c|}{$\begin{array}{l}\text { 4. TITLE AND SUBTITLE } \\
\text { Preliminary Assessment Report for Kent National Guard Facility } \\
\text { (Installation 53065), 24410 Military Road, Kent, Washington }\end{array}$} & 5. FUNDING NUMBERS \\
\hline \multicolumn{4}{|c|}{$\begin{array}{l}\text { 6. } \operatorname{AUTHOR}(\mathrm{S}) \\
\text { Pcter Kctels and Pradecp Aggarwal } \\
\end{array}$} \\
\hline \multicolumn{3}{|c|}{$\begin{array}{l}\text { 7. PERFORMING ORGANIZATION NAME(S) AND ADDRESS(ES) } \\
\text { Candace M. Rose } \\
\text { Argonne National Laboratory } \\
9700 \text { South Cass Avenue } \\
\text { Argonne, IL } 60439\end{array}$} & $\begin{array}{l}\text { 8. PERFORMING } \\
\text { ORGANIZATION } \\
\text { REPORT NUMBER } \\
\quad \text { None }\end{array}$ \\
\hline \multicolumn{3}{|c|}{$\begin{array}{l}\text { 9. SPONSORING/MONITORING AGENCY NAME(S) AND ADDRESS(ES) } \\
\text { National Guard Burcau } \\
\text { Army Directorate } \\
\text { Aberdecn, MD } 21010-5420\end{array}$} & $\begin{array}{l}\text { 10. SFONSORING/ } \\
\text { MONITORING AGENCY } \\
\text { REPORT NUMBER } \\
\text { IR-CR-93084 }\end{array}$ \\
\hline \multicolumn{4}{|c|}{ 11. SUPPLEMENTARY NOTES } \\
\hline \multicolumn{3}{|c|}{$\begin{array}{l}\text { 12a. DISTRIBUTION/AVAILABILITY } \\
\text { Distribution is to government agencies only. } \\
\text { Outside requests must be made to the National Guard Eureau. }\end{array}$} & $\begin{array}{l}\text { 12b. DISTRIBUTION } \\
\text { CODE }\end{array}$ \\
\hline \multicolumn{4}{|c|}{ 13. ABSTRACT (MAXIMUM 200 WORDS) } \\
\hline \multirow{2}{*}{\multicolumn{3}{|c|}{ 14. SUBJECT TERMS }} & $\begin{array}{l}\text { 15. NUMBER OF PAGES } \\
\text { PA-38 }\end{array}$ \\
\hline & & & 16. PRICE CODE \\
\hline $\begin{array}{l}\text { 17. SECURITY } \\
\text { CLASSIFICATION OF } \\
\text { REPORT } \\
\quad \text { Unclassified }\end{array}$ & $\begin{array}{l}\text { 18. SECURITY } \\
\text { CLASSIFICATION OF } \\
\text { THIS REPORT } \\
\quad \text { Unclassified }\end{array}$ & $\begin{array}{l}\text { 19. SECURITY } \\
\text { CLASSIFICATION OF } \\
\text { ABSTRACT } \\
\quad \text { Unclassified }\end{array}$ & $\begin{array}{l}\text { 20. LIMITATION OF } \\
\text { ABSTRACT }\end{array}$ \\
\hline
\end{tabular}




\section{Contents}

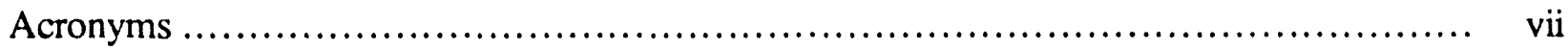

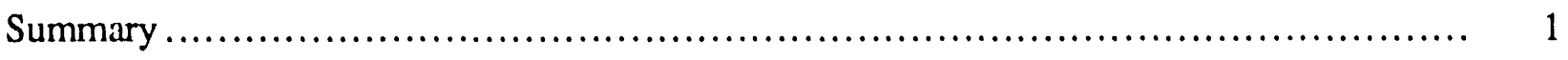

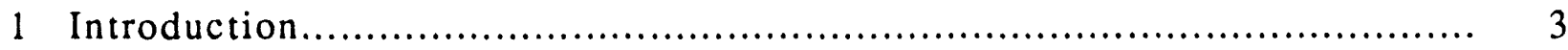

1.1 Authority for the Preliminary Assessment ................................. 3

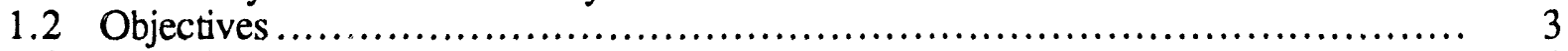

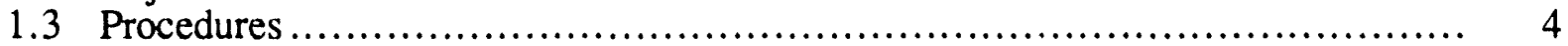

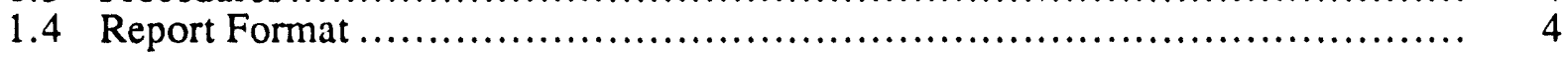

2 Property Characterization ................................................. 5

2.1 General Property Information ................................................ 5

2.2 Description of Facilities..................................................... 5

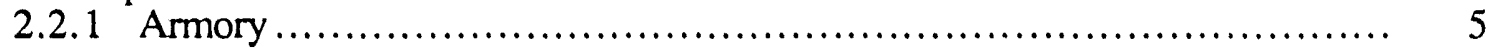

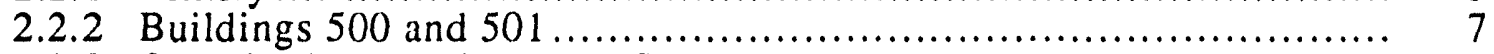

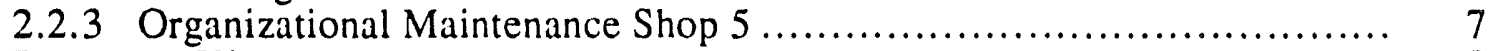

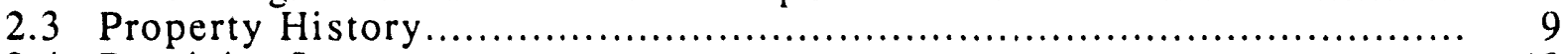

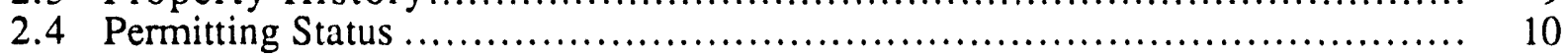

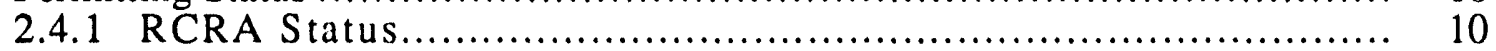

2.4 .2 CERCLA Status ......................................................... 10

2.4.3 Waste Water Permit Status............................................ 10

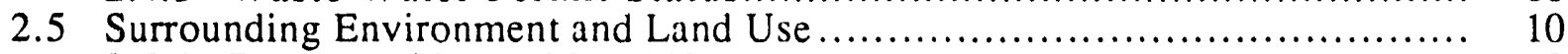

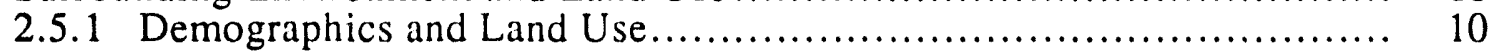

2.5.2 Climate ................................................................. 11

2.5 .3 Surface Water and Physiography $\ldots \ldots \ldots \ldots \ldots \ldots \ldots \ldots \ldots \ldots \ldots \ldots \ldots, \quad 12$

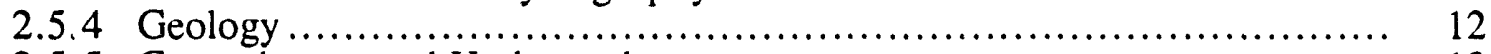

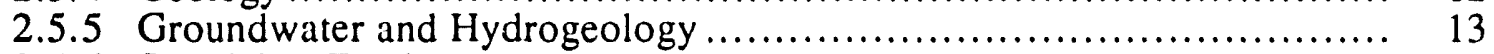

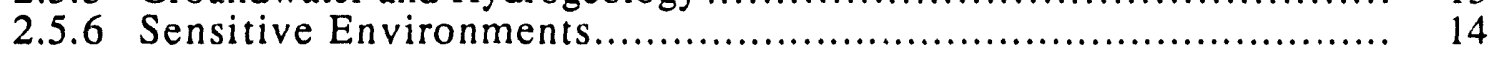

3 Environmentally Significant Operations ..................................... 15

3.1 Underground Storage Tanks .............................................. 15

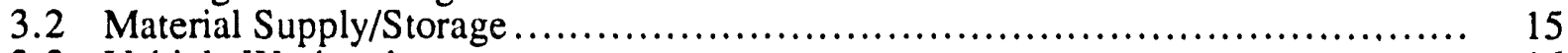

3.3 Vehicle Washrack ........................................................ 16

4 Known and Suspected Releases ....................................... 19

4.1 Releases to Groundwater ............................................ 19

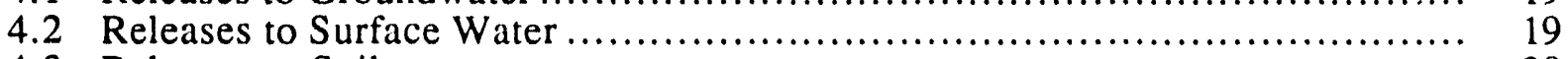

4.3 Releases to Soil ............................................................. 20

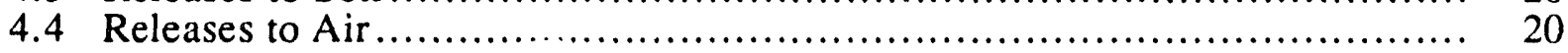

4.5 Other Releases ........................................................... 20

5 Human and Environmental Receptors........................................... 21

5.1 Groundwater............................................................. 21

5.2 Surface Water.............................................................. 21

5.3 Soil.................................................................. 21 


\section{Contents (Cont.)}

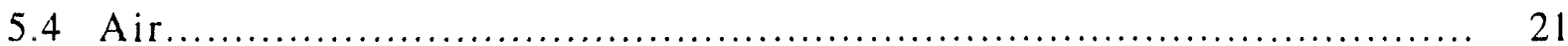

5.5 Other Receptors......................................................... 22

6 Preliminary Assessment Findings and Conclusions $\ldots \ldots \ldots \ldots \ldots \ldots \ldots \ldots \ldots \ldots \ldots .23$

6.1 Summary of Preliminary Assessment Findings ............................ 23

6.2 Recommendations for Further Action ................................... 23

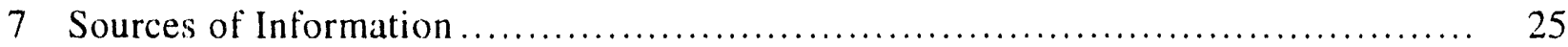

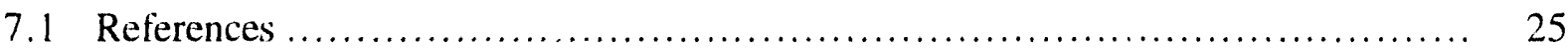

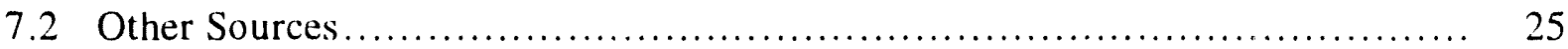

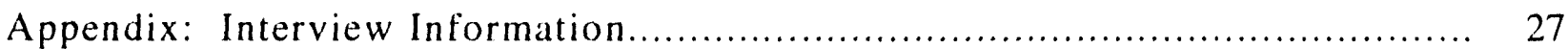

Figures

1 General Location of Kent National Guard Facility .......................... 6

2 Locations of Environmentally Significant Operations at Kent National

Guard Facility 8

\section{Tables}

1 Identifying Information for Kent National Guard Facility ...................... 7

2 Organizational Maintenance Shop No. 5 Workplace Supply List, March 1993.... 17 


\section{Acronyms}

CERCLA Comprehensive Environmental Response, Compensation, and Liability Act

DRMO

Defense Reutilization and Marketing Organization

EPA

U.S. Environmental Protection Agency

ESO environmentally significant operation

FISP

Facility Inventory and Stationing Plan

IRP Installation Restoration Program

OMiS

Organizational Maintenance Shop

PA preliminary assessment

POL petroleum, oils, and lubricants

RCRA Resource Conservation and Recovery Act

SCS Soil Conservation Service

USGS U.S. Geological Survey

UST underground storage tank

WAARNG Washington Army National Guard WSDOE

Washington State Department of Ecology 


\section{Preliminary Assessment Report for \\ Kent National Guard Facility \\ (Installation 53065), \\ 24410 Military Road, \\ Keni, Washington}

\section{Summary}

This report presents the results of the preliminary assessment (PA) conducted by Argonne National Laboratory at the Washington Army National Guard property in Kent, Washington. Preliminary assessments of federal facilities are being conducted to compile the information necessary for completing preremedial activities and to provide a basis for establishing corrective actions in response to releases of hazardous substances. The principal objective of the PA is to characterize the site accurately and determine the need for further action by examining site activities, quantities of hazardous substances present, and potential pathways by which contamination could affect public health and the environment. This PA satisfies, for the Kent National Guard Facility property, Phase I of the Department of Defense Installation Restoration Program.

The Kent National Guard Facility is a 14.08-acre site located in the northwest portion of Washington, about 9 mi south of the City of Seattle, in King County. The facilities included in this PA are Organizational Maintenance Shop No. 5 (OMS 5) and the armory. The environmentally significant operations associated with the property are (1) underground storage tanks, (2) materials supply/storage, and (3) the vehicle washrack.

The review of both historical and current practices at the property indicated that the Kent National Guard Armory facility does not pose a substantial risk to human health or the environment, although Argonne's reviewers noted several areas of concern. The first area of concern is the potential for contamination of soil and groundwater due to past waste disposal practices of discarding spent solvents and battery acid (diluted or neutralized) into drains connected to a series of dry wells. The presence and extent of any such contamination, which are presently unknown, should be investigated by field sampling and analysis of the soil and groundwater in the vicinity of the dry wells. This task should be given a high priority because of the proximity of the Kent National Guard Facility to the Sunnycrest Elementary School and the location of a dry well on the school playground. 
The second area of concern is also related to the system of dry wells. The drain in the battery storage room in Building 506 was once connected to the dry well system, as was the vehicle washrack drain. The washrack has recently been connected to an oil-water separator and to the municipal drain system. Whether the battery storage room drain has also been connected to the sanitary sewer system is not known.

A third area of concern is the need for spill containment in the storage shed for petroleum, oils, and lubricants. Several potentially hazardous materials are stored in the shed, and no provisions for spill containment are evident. No record of a significant spill in the past is available, but some provision should be made for containment to prevent future spills from contaminating the environment; construction of a curb around the floor of the shed is recommended.

The fourth area of concern is the unknown location of an abandoned underground fuel oil storage tank. Early site plans show the existence of a gas dock near the school playground. The tank should be located and verified to be empty, and the appropriate closure report should be filed with the state. Ideally, the tank should be removed at some time in the future.

During the site visit, several 2.5-ton cargo vehicles were parked in the grassy area along the north edge of the OMS 5 parking lot. These vehicles were backed up to the fence that separates the site from the school playground. This area is not paved. If a fuel tank were to leak or burst, the contents would run very near to or onto the school playground, posing a potential threat to the children. This practice should not be allowed to continue, because ample parking is available in other areas of the site, on paved areas distant from the school. 


\section{Introduction}

This document is a report of the preliminary assessment (PA) conducted by Argonne National Laboratory at the Washington Army National Guard (WAARNG) property known as the Kent National Guard Facility, located in Kent, Washington.

\subsection{Authority for the Preliminary Assessment}

The National Guard Bureau, Army Directorate, has engaged Argonne to perform PAs of selected National Guard properties. These assessments are being done in a manner consistent with both the Department of Defense Installation Restoration Program (IRP) and the U.S. Environmental Protection Agency's (EPA's) Potential Hazardous Waste Site Preliminary Assessment Guidance. Preliminary assessments of National Guard properties are conducted under the authority and direction of the IRP; the Comprehensive Environmental Response, Compensation, and Liability Act (CERCLA or, more commonly, Superfund); and the Superfund Amendments and Reauthorization Act of 1986 (Public Law 99-499).

\subsection{Objectives}

This PA report is based on existing information from the National Guard records that were made available to Argonne investigators and from other sources. Although this PA effort did not extend to the generation of new data, it nonetheless identifies areas where existing data are incomplete, unreliable, or ambiguous and recommends ways to address such shortcomings.

The objectives of the PA are to satisfy Phase I of the IRP and to

- Identify and characterize the environmentally significant operations (ESOs),

- Identify property areas or ESOs thrit may require a site investigation,

- Identify ESOs or areas of environmental contamination that may require immediate removal,

- Identify properties for which no further action is needed, and 
- Provide information sufficient to prescore the site with the EPA's PA Scoresheets (September 1991).

\subsection{Procedures}

The PA began with a review of WAARNG files located at Camp Murray, Tacoma, Washington, on May 18, 1993. A site visit was conducted on May 19,1993, to obtain additional information through direct observation and interviews with personnel familiar with the property and its operations. Other relevant information was obtained on May 20-21, 1993, from the Washington State Department of Ecology, Olympia, Washington; the State Department of Ecology, Bellevue, Washington; the city of Seattle Water Department; the city of Kent; and King County.

\subsection{Report Format}

This PA report presents a summary and evaluation of the data relevant to the PA for this property. Section 2 describes the property and its surrounding environment and land uses. Section 3 identifies and characterizes the ESOs at the site. Section 4 discusses known and suspected releases to the environment, and Section 5 discusses potential human and environmental receptors for such releases. Section 6 summarizes the findings and conclusions, discusses the quality and reliability of the supporting information, identifies areas requiring further action, and (as appropriate) suggests how such actions can be accomplished. Section 7 lists pertinent materials reviewed. The Appendix gives interview information. 


\section{Property Characterization}

\subsection{General Property Information}

The Kent National Guard Facility is operated by the WAARNG under license from the Department of the Army. The facility is used by the Third Battalion, 161st Infantry Mechanized, which is made up of Headquarters Company, Alpha Company, Bravo Company, and the 341st Military Intelligence Battalion. The license, last renewed in 1989, is for an indefinite period (minimum requested, 50 years). Figure 1 shows the general location of the property, and Table 1 lists pertinent information about it.

\subsection{Description of Facilities}

The Kent National Guard Facility, shown in Figure 2, consists of 14.08 acres with seven buildings, a vehicle washrack, and waste storage for hazardous chemicals. The facility is located within the city limits of Kent and is surrounded primarily by single-family residences. Sunnycrest Elementary School and playground abut the eastern property line of the site. The site is secured by a chain link fence and a locked gate after hours, with no sentry on duty.

\subsubsection{Armory}

The main armory, built in 1989 , is a $52,000-\mathrm{ft}^{2}$ single-story structure used for administration, with facilities for classroom instruction. No field training takes place at the site; equipment is checked out and returned after use in weekend training exercises. The site of the new armory was formerly occupied by buildings 400,420 , and 421 , which were demolished to allow construction of the new armory. Little information is available on the old buildings except that they were part of the former Nike control site. Building 400 was a mess hall. The current site has no me $s$ facilities. 


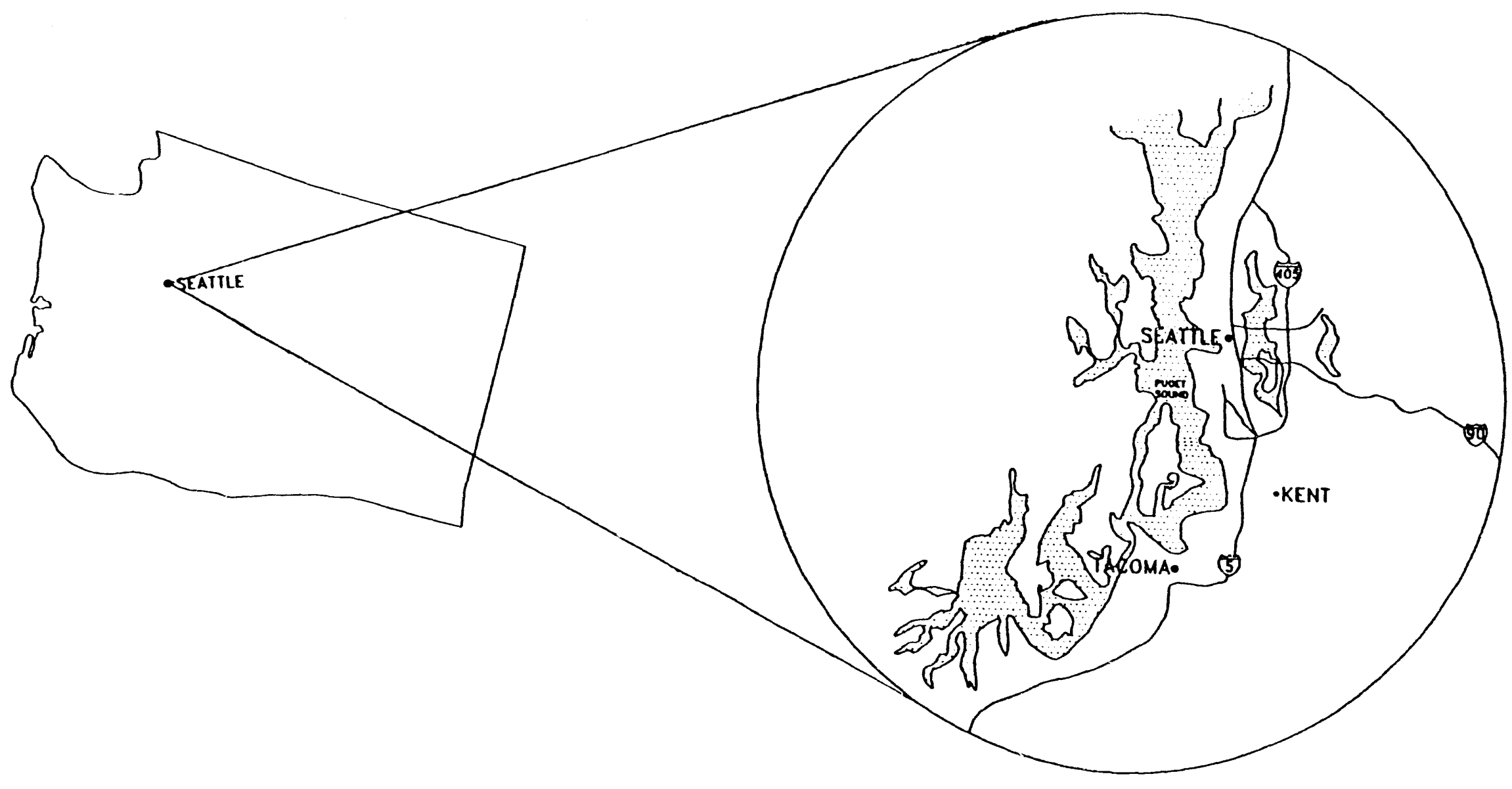

FIGURE 1 General Location of Kent National Guard Facility (Sources: USGS 1973a-d) 
TABLE 1 Identifying Information for Kent National Guard Facility

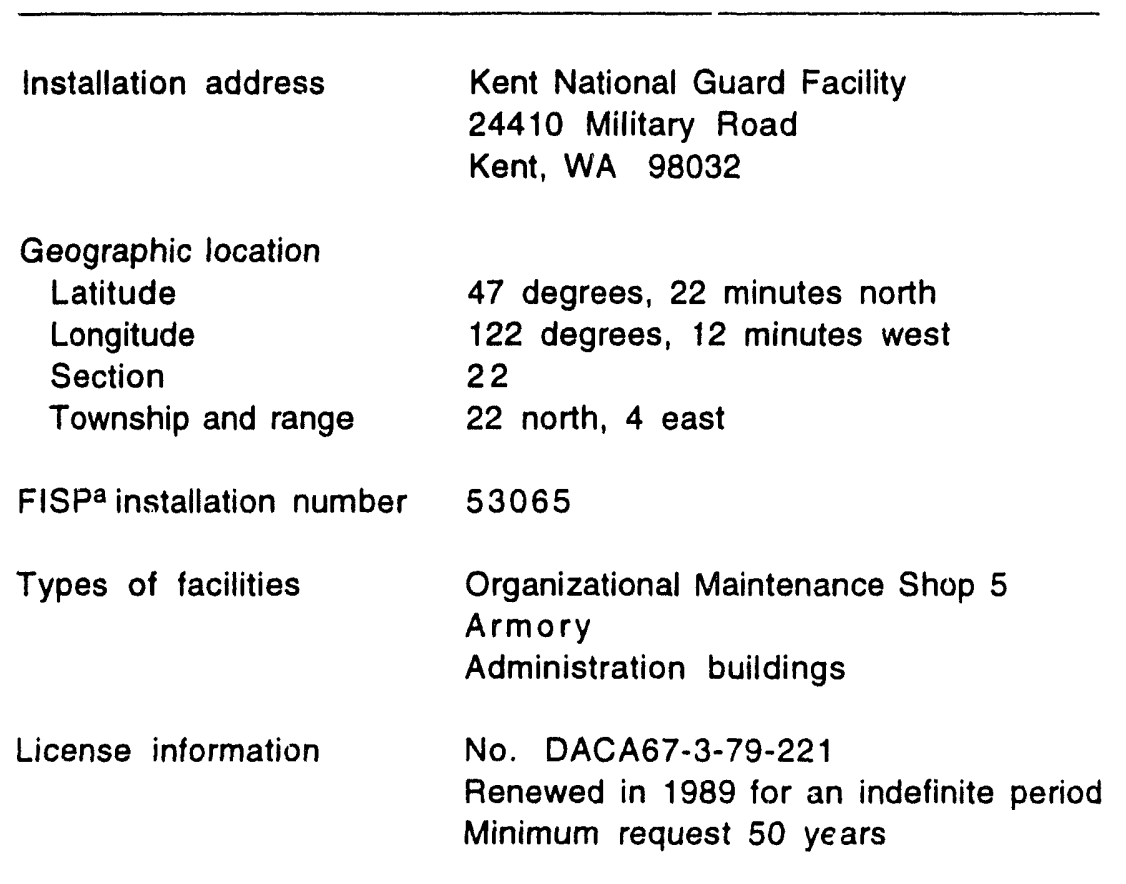

a Facility Inventory and Stationing Plan.

\subsubsection{Buildings 500 and 501}

Building 500 is used for storing equipment required for weekend training exercises. This equipment is checked out at the beginning of an exercise and returned upon completion of the exercise. Building 500 is usually attended by one person during the week.

Building 501 houses the 341 st Military Intelligence Battalion. Five or six Nationai Guard personnel are usually in the building on weekdays.

\subsubsection{Organizational Maintenance Shop 5}

The OMS 5 provides routine maintenance for National Guard vehicles. Seven structures are associated with the operation of OMS 5. Building 414 is a flammables storage area for acetylene cylinders. A Connex storage building about $20 \mathrm{ft}$ to the south of Building 414 is used for storing oxygen cylinders. A gas dock, described in Section 3.1, is east of Building 506. Building 507 is the OMS 5 office for supervisory personnel and equipment maintenance records. 


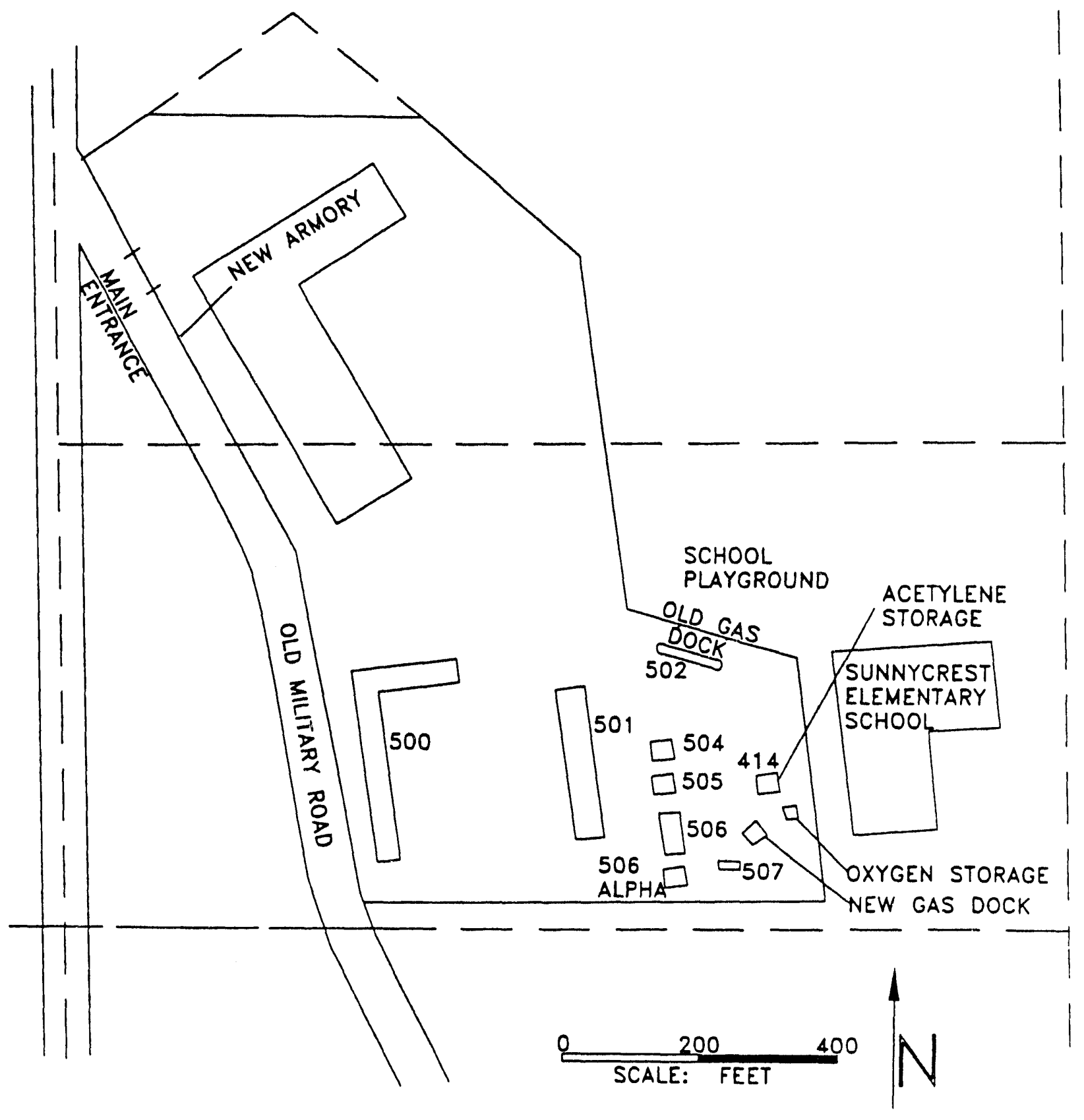

FIGURE 2 Locations of Environmentally Significant Operations at Kent National Guard Facility 
Building 506, the main OMS 5 shop, is $35 \mathrm{ft} \times 60 \mathrm{ft}$ and has three vehicle work bays and two separate rooms at its south end. One room is for storage of vehicle batteries, and the other is for storage of maintenance supplies. The shop is equipped with a vacuum system that is used for working on vehicle brakes, to minimize exposure to asbestos particles. Parts are cleaned in an orange-citrus-based solvent. No floor drains are in the shop area. A spill would run out through the bay doors into the parking area in the direction of the gas dock. During the site visit the shop work area appeared clean and orderly.

Immediately to the south of Building 506 is an all-metal structure approximately $30 \mathrm{ft} \times 30 \mathrm{ft}$. This building, designated 506 Alpha, contains storage cribs for equipment required by various National Guard units housed at the facility.

Immediately to the north of Building 506 are the vehicle washrack and Building 504, a petroleum, oils, and lubricants (POL) storage shed. The washrack is used for pressure washing and steam cleaning of vehicles as required. The POL storage shed is a fully enclosed metal structure for storing oils and lubricants used in vehicle maintenance.

The OMS 5 maintains a fleet of approximately 90 vehicles consisting of the following:

- 38 HMMWVs (High Mobility Multipurpose Wheeled Vehicles)

- 35 2.5-ton cargo trucks

- 16 5-ton cargo trucks

- 1 HEMTT (High Expanded Mobility Tactical Truck) wrecker

Vehicles from other WAARNG sites in the region, such as Redmond, are also serviced at OMS 5. About 5-10 personnel are in OMS 5 during the week and about 80 on weekends during training exercises.

\subsection{Property History}

The Kent National Guard Facility, originally known as the Seattle Defense Area Nike Battery 43 Military Reservation, consisted of three distinct parcels of land: a control area, a family 
housing area, and the actual Nike missile launch area. In 1973, 14.08 acres of the original control area were assigned to the WAARNG. This is the only area of concern in this report. The launch area is no longer under the control of the Department of the Army, but the housing area is still in the U.S. Army inventory.

\subsection{Permitting Status}

\subsubsection{RCRA Status}

This installation has no ESOs that require a RCRA permit.

\subsubsection{CERCLA Status}

No ESOs at this installation are designated for CERCLA activities.

\subsubsection{Waste Water Permit Status}

No waste water discharge permits are required in connection with the ESOs at this site.

\subsection{Surrounding Environment and Land Use}

\subsubsection{Demographics and Land Use}

King County extends approximately $50 \mathrm{mi}$ in an east-west direction and $40 \mathrm{mi}$ in a northsouth direction, with its western boundary lying in Puget Sound. The greater Seattle metropolitan area lies within King County, and the city of Kent is within this metropolitan area. Kent is appı `...mately 9 mi south of Seattle. The estimated population of Kent (1990 census) is 37,960, an increase of 14,999 over the 1980 census. The estimated population of King County (1990 census) is $1,507,319$, an increase of 237,421 over the 1980 census.

The Kent National Guard Facility is completely surrounded by residential areas and some small commercial development. The Sunnycrest Elementary School immediately adjoins the site 
on its eastern perimeter. All nearby structures are served by municipal water and sewer systems operated by the city of Kent.

The Midway Landfill is located $0.6 \mathrm{mi}$ to the west of the Kent National Guard Facility immediately west of Interstate 5, which runs north-south. This landfill, located in an old gravel quarry, was in operation from 1969 to 1983. Unknown quantities of solvents, organic and inorganic chemicals, heavy-metal wastes, and dredge and fill materials containing aromatic and chlorinated hydrocarbons were discarded on this site. No protective layer wa placed between the landfill and the local groundwater, which is believed to flow in a southwesterly direction. Releases of heavy metals and organic chemicals have been confirmed by groundwater analysis. This site has been designated a Superfund site by the U.S. Environmental Protection Agency, Region 10.

In addition, in 1984 the city of Seattle installed gas-monitoring equipment in the soil adjacent to the landfill, and elevated levels of methane gas were detected. Subsequent studies have revealed the presence of elevated methane concentrations in the soil east and southwest of the landfill at a distance of up to 2,500 ft. Extraction wells have been installed and have been reported to be successful in reducing the methane concentration to acceptable levels.

\subsubsection{Climate}

King County is located at approximately 47-48 degrees north latitude in a temperate climate zone. The latitude and longitude of the Kent National Guard Facility are 47 degrees, 22 minutes north; 122 degrees, 12 minutes west. The mean monthly temperature in Seattle, the nearest reporting station, varies from $38^{\circ} \mathrm{F}$ in January to $65^{\circ} \mathrm{F}$ in July. The prevailing wind direction is from the south during most of the year. The site is approximately $4 \mathrm{mi}$ south of Seattle-Tacoma International Airport, which is the site of the meteorological reporting station. Wind speed and direction may differ from those at the airport because of topographic conditions. The mean wind speed, approximately $8 \mathrm{mi} / \mathrm{hr}$, is fairly uniform throughout the year.

Topographic features cause rainfall in King County to be highly dependent on the specific location under consideration. Kent lies within the lowlands surrounding Puget Sound and receives about 41 in. of rainfall per year. December is the wettest month, and July or August the driest month of the year. Thunderstorms are uncommon, averaging about five per year. 


\subsubsection{Surface Water and Physiography}

Southwestern King County lies in the Puget Sound lowland. The lowland, located between the Cascade Mountains on the east and the Olympic Mountains on the west, consists of broad, relatively level drift plains. The surface of the drift plain is about $400-600 \mathrm{ft}$ above sea level. Four major rivers, the Puyallum, White, Green, and Cedar, occur in the area and serve as convenient boundaries for physiographic subdivisions.

The Kent National Guard Facility is located in the Duwamish Valley physiographic unit on a hilly tract of land about $400 \mathrm{ft}$ above mean sea level. The nearest surface water body is Midway Creek, whose head lies about $500 \mathrm{ft}$ north of the site. Midway Creek flows into the Green River about $1 \mathrm{mi}$ north. Surface drainage from the site is to the north and east into Midway Creek.

Soils in the Kent area are classified as gravelly, sandy loams in the uplands and silty clay in the bottomlands (SCS 1973). The upland soils are Everett gravelly, sandy loam with excessive drainage. The bottomland soils are Puget silty clay and Puyallum fine sandy loam/silty loam.

\subsubsection{Geology}

The geology of southwestern King County consists of consolidated rocks and semiconsolidated to unconsolidated materials (Luzier 1967). Consolidated rocks of Tertiary age are the bedrock in the area. The bedrock crops out in the northwestern portion of the country (near Seattle) and is buried beneath several hundred feet of unconsolidated deposits in other places. The consolidated rocks consist primarily of sedimentary rocks, shale, graywacke, sandstone, and conglomerate, as well as some volcanic rocks of andesitic composition.

Unconsolidated deposits of Quaternary age overlie the bedrock in most of northwest King County. These deposits consist of sediment derived from three principal areas: (1) the Mount Rainier volcano, (2) the central Cascade Range to the east, and (3) British Columbia and the northern Cascade Range in Washington. The source areas of the se iinents can be identified on the basis of the rock types, which are distinctively different in the three area.

The unconsolidated deposits consist of five principal units, the Orting and Intermediate

drifts, the Salmon Springs drift, the pre-Vashon drift, the Vashon drift, and the postglacial deposits. The Orting and Intermediate glacial drift deposits are the oldest (Pleistocene age) 
deposits overlying the Tertiary bedrock. The Puyallum Formation consists of mudflows, volcanic ash, fine to medium sand, and minor drift deposits lying between the Orting/Intermediate drift and the Salmon Springs drift, consisting of sand and pebble-cobble gravel with minor till, silt, and clay. The Salmon Springs drift is overlain by the pre-Vashon drift, which consists of at least four layers of gray till separated by fluvial sand and gravel and a thick sequence of oxidized lacustrine sand, silt, clay, peat, and fluvial sand and gravel. The Vashon drift consists of advance and recessional outwash deposits and a till unit. Postglacial deposits consisting of peat and swamp materials, mudflows, and alluvium overlie the Vashon drift.

In the vicinity of the Kent National Guard Facility, the unconsolidated deposits range in thickness from a few hundred feet to more than $1,000 \mathrm{ft}$.

\subsubsection{Groundwater and Hydrogeology}

The consolidated Tertiary rock is not a significant source of water in most of southwestern King County. Groundwater is obtained from all units of the Quaternary deposits. The most productive aquifers are in the glacial outwash deposits of the Salmon Springs drift and the advance and recessional outwash deposits of the Vashon drift. Water can be obtained almost everywhere in southwestern King County from these deposits (Luzier 1967). Large yields are obtained where a considerable thickness of coarse-grained material occurs within the zone of saturation.

Significant sources of groundwater are also found in the highly permeable gravel lenses at a depth of about $20 \mathrm{ft}$ in the postglacial deposits that overlie the Vashon drift, particularly on the floors of major stream valleys.

In the vicinity of the Kent National Guard Facility, the uppermost aquifer is in the outwash deposits of the Vashon drift at a depth of about 20-225 ft. The outwash aquifers are generally perched and have a saturated thickness of several inches to several feet. A gravel bed in the lower part of the outwash deposits is a productive aquifer.

Underlying the outwash gravels is a second aquifer in a sand layer about 20-60 ft thick with intervening silt, clayey silt, and silty fine sand. The sand aquifer is confined at the bottom and the top by silt aquitards. A third aquifer occurs in gravel at a depth of about $300 \mathrm{ft}$. This aquifer lies beneath the lower confining silt of the sand aquifer and consists of 5-30 ft of sandy gravel deposits. 
Groundwater flow directions in the vicinity of Kent vary within each aquifer. However, the dominant flow in both the upper gravel aquifer and the sand aquifer is toward the southeast. The flow direction in the lower gravel aquifer is to the southwest.

A large number of domestic, municipal, and irrigation wells are located in the Kent area. The nearest domestic well is located about $1 \mathrm{mi}$ southeast of the Kent National Guard Facility, at the northern tip of Lake Fenwick.

The city of Kent obtains its water from both groundwater wells and surface water sources. Groundwater constitutes about $60 \%$ of the total water supply and is withdrawn from wells located more than 4 mi northeast of the National Guard Facility.

\subsubsection{Sensitive Environments}

No environmentally sensitive areas were identified within a 4-mi radius of the Kent National Guard Facility. 


\section{Environmentally Significant Operations}

The PA team from Argonne identified three ESOs at the Kent National Guard Facility: (1) underground storage tanks (USTs), (2) materials supply/storage, and (3) the vehicle washrack. Figure 2 shows the general locations of the ESOs.

\subsection{Underground Storage Tanks}

Two USTs are known to exist at the Kent facility. These tanks, installed in 1987, are a 5,000-gal tank for diesel fuel and a 1,100-gal tank for unleaded gasoline. The tanks are located east of the OMS 5 building (Building 506 in Figure 2). The tanks are under the concrete apron associated with the fuel pumps. A catch basin surrounds the area around the concrete apron to prevent any spilled fuel from running onto the ground. The drain from the catch basin empties into a oil-water separator, and the water then flows into the storm sewer system. The tanks are doublewalled carbon steel equipped with overfill protection and cathodic protection against corrosion. These tanks are continuously monitored for leak detection and were last tested for tightness in 1992. They are due to be tested again in 1997.

A third UST, installed in 1956 and out of service since 1975, is believed to exist. This tank was used to store diesel fuel, and it is currently believed to be empty. Its exact location is unknown. In addition, three other USTs were removed in 1987: a 5,000-gal gasoline tank, a 2,000-gal diesel fuel tank, and a 250-gal waste oil tank. No documentation exists concerning the condition of these tanks at the time of their removal.

\subsection{Material Supply/Storage}

Storage of materials relating to the operation of OMS 5 is confined primarily to a POL shed located to the north of the washrack, designated Building 504 in Figure 2. This shed is entirely enclosed and has a concrete floor with no spill containment provision. Motor oil, small quantities of solvent, and some lubricants are stored in the POL shed.

Battery acid and vehicle batteries are stored in a room inside OMS 5, Building 506. The room is located in the southwest comer of the building. The room contains a sink and a floor drain. The drains are connected to a series of dry wells. Paint and paint thinner are stored in a 
room next to the battery room in Building 506. These products are stored in metal cabinets that are clearly marked as to their contents. Table 2 lists the types of materials stored. No evidence of spillage was observed by the Argonne PA team during the site visit. All wastes and the used vehicle batteries generated at OMS 5 are collected and sent to Camp Murray in Tacoma for further disposal through the Defense Reutilization and Marketing Office (DRMO) or by private vendor.

\subsection{Vehicle Washrack}

A vehicle washrack located inmediately to the north of Building 506 is connected to an oil-water separator that was recently installed. Before the modification of the drain system, drainage occurred directly through a system of dry wells. During the site visit, the area surrounding the washrack appeared to be clean and free from spills. 
TABLE 2 Organizational Maintenance Shop No. 5 Workplace Supply List, March 1993

Trade Name/Nomenclature

Supply Number

Sealing compound, Saf-T-Loc

$8030-00-081.2335$

Adhesive, wood

Dry lube/super lube

$8040.00-063.2835$

$\mathrm{X}-50180$

Wool, steel

Correction, fluid

Vision aid, liquid-anti-fog

Adhesive cyanoacrylate, Super Glue

Liquid protectant

Wood adhesive

Ink, stamp pad

Hand screen protective

Cleaner fluid, patch rubber

Trichloroethane

Electra-Seal, anti-corrosion

Break-Away-Mantek, antiseize

T-Shield battery coating

Insecticide, aerosol

WD-40 penetrant

Fuel primer ether

$7510-01-020-2806$

$8040-00-142-9193$

$8030-01-103-2868$

$8040-00-063-2835$

$7510-00-161-4240$

$\times 53-0766$

$6810-00-930-6311$

Adhesive rubber

Permatex, Form A gasket adhesive

Lock Tight EPI seal

Adhesive, sealant

Cleaning compound, windshield

Penetrating fluid

Corrosion preventive $\mathrm{CP}$

Lubricant, inner tube

Cleaner lubricant CLP

Rust-Tek

Hand soap

Safety Kleen solvent

Sulfuric acid

Ammonia/detergent

Isopropyl alcohol mixture

Grease, graphite

Tent patch

Belt dressing

Pentron-Penetrant/Mantek

Chlorodifluoromethane/SP kit

Gasket sealer

Detergent - general purpose

$6840-01.067 .0674$

6850-00-823-7861

8040-00-262-9031

$8040-00-738-6429$

$8040-00-225-4548$

$6850-00-973-2275$

6850-00-973-9091

$8030-00-838-7789$

2640-00-264-6642

$9150-01-054-6453$

$6630-00-169-1506$

Deicing fluid

Rusty - penetrant

Hydraulic fluid/jacks

Lubricant/tire rim

Thinner, epoxy

Propane/dimethylmethane

$6810-00-893-8138$

$8030-00-252-3391$

$8040-00-273-8717$

$\times 26000-01330$

$\times 656.1426$

$7930-00-357-7386$

$6850-00-835.0484$

$\times 50065$

2640-00-256-5527

$8010-01-212-1704$

6830-00-584-3041 
TABLE 2 (Cont.)

\begin{tabular}{lc}
\hline \multicolumn{1}{c}{ Trade Name/Nomenclature } & Supply Number \\
\hline & \\
Dixon graphite & \\
Toluene/methylstyrene & \\
Brake fluid, silicon & \\
Cleaning compound/engine & Not regulated \\
OHT fluid & $00-935-9807$ \\
Antifreeze & $6850-00-181-7933$ \\
Dry cleaning solvent & $00-264-9038$ \\
Water reagent & $6810-00-356-4936$ \\
Antiseize & $8030-00-597-5362$ \\
LSA grease & $9150-00-687-4241$ \\
Purple-K-Fire ext & $4210-00-257-5343$ \\
Acetylene, ethyne & $74-86-2$ \\
Oxygen & $7782-44-7$ \\
Plast-N-Glas/CTR screen & $X 8400$ \\
Bees wax/furniture & \\
Hydraulic fluid & $9150-00-698-2382$ \\
Lub oil HDO- & MIL-L-2104 \\
Fyrquel/FRH MIL-L-23699C & $9150-00-111-6254$ \\
Grease auto & $9150-00-190-0907$ \\
Hand cleaner paste & $8520-00-782-2183$ \\
\hline
\end{tabular}




\section{Known and Suspected Releases}

\subsection{Releases to Groundwater}

A system of interconnected dry wells has been known to exist at the Kent National Guard Facility for some time. These dry wells probably date back to the mid 1950s, when the facility was first used as a Nike battery site. The depths of the dry wells are unknown. One of the dry wells is located in the paved schoolyard of the Sunnycrest Elementary School. The drain in the battery room in Building 506 may still be connected to this dry well system.

Before 1984, discarded battery acid was diluted with water and poured into the drain in the battery storage room, eventually reaching the dry well system. An estimated $452 \mathrm{lb}$ of acid were discarded in this manner in 1987. This estimate is taken from a Dangerous Waste Report that the WAARNG was required to file with the Washington State Department of Ecology (WSDOE).

According to verbal accounts, in the past, used solvents were discarded by simply pouring them into the drain in the battery room. The solvent entered the dry well system along with the battery acid. No documentation of this practice exists. An estimate of the amount of spent solvent discarded per year was obtained from the 1987 Dangerous Waste Report filed with the WSDOE, which stated that $1,800 \mathrm{lb}$ of spent petroleum naphtha was generated in 1987 . This could be a reasonable estimate of the amounts generated in the past. The solvent was used to clean vehicle and motor parts during maintenance operations. An orange-citrus-based cleaning system is now used for parts cleaning. This system is environmentally friendly, and spent solvent is recycled through the DRMO at Camp Murray.

Because of these suspected past disposal practices, the probability of releases to groundwater is very high. The presence or absence of contamination in the groundwater at the Kent National Guard Facility has not been confirmed by sampling.

\subsection{Releases to Surface Water}

No evidence, documented or observed, of releases to surface water was found at the Kent National Guard Facility. Rainwater runoff from the site flows to the north onto the playground of 
the Sunnycrest Elementary School and then down to a ravine cut into the valley wall by a spring. Eventually, runoff will merge with the outflow of the spring and flow to the Green River.

\subsection{Releases to Soil}

As Section 4.1 indicates, past disposal practices for spent battery acid and solvent may have resulted in releases to the soil via the dry well system. The presence or absence of contamination has not been confirmed by sampling of the dry well or soil. Anecdotal reports indicate that many years ago waste oil was collected in 55-gal drums and sprayed on unpaved roads within the site as needed to control dust. How long this practice was continued is not known. Currently, all roads and parking areas on the site are paved.

\subsection{Releases to Air}

No documentation of any atmospheric emissions of toxic substances were found for this installation.

\subsection{Other Releases}

No releases related to a threat from fire or explosion were documented or observed during the site visit. 


\section{Human and Environmental Receptors}

\subsection{Groundwater}

The city of Kent is served by a municipal water system. Water is purchased from the city of Seattle Water Department, which obtains water in the foothills of the Cascade Mountains. The nearest privately owned wells are approximately $1 \mathrm{mi}$ from the Kent National Guard Facility. Both are listed as domestic water supply wells, but no information is available about their current status. Water from two nearby springs, $0.3 \mathrm{mi}$ from the site, is used for domestic purposes. The spring nearest the site, just north of the school playground, is used for irrigation.

\subsection{Surface Water}

As Section 4.2 indicates, surface runoff from the Kent National Guard Facility will flow north across the schoolyard of the Sunnycrest Elementary School and into the ravine on the other side, mixing with the outflow from the spring located there. The small creek flows into the Green River after about $0.8 \mathrm{mi}$, and the Green River flows into Puget Sound about $20 \mathrm{mi}$ downstream. The extent of public and private use of the Green River is unknown. As previously mentioned, the water from the spring is used for irrigation.

\subsection{Soil}

The Kent National Guard Facility is secured by fences that reduce the possibility of direct contact with any potentially contaminated soil by persons not authorized to be on the site. Contact would be limited to WAARNG personnel and authorized visitors. The number of personnel on the site on weekdays is approximately 20-40. On weekends the number may increase to more than 500 because of attendance at training exercises. In addition, children could come into contact with soil on the school playground if contamination was found there.

\subsection{Air}

On-site personnel and local residents in the immediate area are potential receptors of any atmospheric emissions of toxic or hazardous substances from the Kent National Guard Facility. 


\subsection{Other Receptors}

Flammable and potentially explosive substances at the Kent National Guard Facility are stored in a way that minimizes any threat to human health and the environment from fire or explosion. No evidence exists to indicate a history of fire or explosions at this site. Any incident of this type would affect WAARNG personnel and residents in the immediate vicinity of the site, including those in attendance at the Sunnycrest Elementary School. The facility has an active emergency response plan on file with the city of Kent, to respond to fires, explosions, and spills of hazardous materials. 


\section{Preliminary Assessment Findings and Conclusions}

\subsection{Summary of Preliminary Assessment Findings}

The WAARNG facility located in the city of Kent, Washington, comprises approximately 14 acres in King County. The site is surrounded primarily by private, single-family residences. The principle ESOs of concern are (1) USTs, (2) materials supply/storage, and (3) vehicle washracks.

The PA examined the nature of the surrounding area and the operations at the Kent National Guard Facility to identify direct pathways for potential environmental impact. The review of available information and direct observation indicate that no current operation poses a significant threat to human health or the environment. However, the possibility does exist that past disposal practices for spent solvent and battery acid resulted in releases to the soil and groundwater.

\subsection{Recommendations for Further Action}

The primary objective of this PA was to identify and evaluate ESOs that would result in (1) immediate action, (2) a site inspection, or (3) no further requirement for PA/IRP action. On the basis of available information, including the site visit, the Kent National Guard Facility does not present an imminent threat to human health and the environment. However, areas of concern do exist, which the WAARNG should pursue.

The first area of concern is the possibility that the dry well system is significantly contaminated because of past disposal practices for spent solvent and battery acid. Field sampling and analysis of the soil and groundwater in the vicinity of the dry wells is necessary to disprove or confirm the possibility of contamination. This task should be given a high priority because of the proximity of the site to the Sunnycrest Elementary School and the location of a dry well on the school's playground.

The second area of concern is also related to the dry well system. The drain in the battery storage room in Building 506 was at once connected to the dry well system, as was the vehicle washrack drain. The washrack has recently been connected to an oil-water separator and to the 
municipal drain system. Whether the battery storage room drain has also been connected to the sanitary sewer system is not known. This determination should be made as soon as practical.

A third area of concern is the need for spill containment in the POL storage shed. Several potentially hazardous materials are stored in the shed, and no provisions for spill containment are evident. No record of a significant spill in the past was available, but some provision should be made for containment to prevent future spills from contaminating the environment; construction of a curb around the floor of the shed is recommended.

The fourth area of minor concern is the unknown location of an abandoned UST. The tank should be located and verified to be empty, and the appropriate closure report should be filed with the state. Ideally, the tank should be removed at some time in the future.

The last area of concern, observed during the site visit, is cargo trucks parked along the fence bordering the school playground. The trucks were backed up to the fence in a grassy area just off the paved parking lot. The basis of concern is the possibility of vehicle fuel tank failure, which could allow leaking fuel to run onto the school playground just on the other side of the fence. 


\section{Sources of Information}

\subsection{References}

Luzier, J.E., 1967, Geology and Groundwater Resources of Southwestern King County, Washington, Washington Division of Water Resources, Water Supply Bulletin 28.

SCS, 1973, Soil Survey of King County, Soil Conservation Service, U.S. Department of Agriculture.

USGS, 1973a, Topographic Map - Auburn, Washington, Quadrangle, U.S. Geological Survey 7.5 minute quadrangle.

USGS, 1973b, Topographic Map - Des Moine, Washington. Quadrangle, U.S. Geological Survey, 7.5 minute quadrangle.

USGS, 1973c, Topographic Map - Poverty Bay, Washington, Quadrangle, U.S. Geological Survey, 7.5 minute quadrangle.

USGS, 1973d, Topographic Map - Renton, Washington, Quadrangle, U.S. Geological Survey, 7.5 minute quadrangle.

\subsection{Other Sources}

City of Seattle Water Department, 1993, Water Supply Plan, City of Seattle, March.

City of Seattle Water Department, 1992, Water Supply Plan, Draft Environmental Impact Statement, August.

King County, 1992, King County Annual Growth Databook, 1992, Planning and Community Development Division, August. 
King County, 1992, King County Census Bulletin \#1, 1990 Census, Planning and Community Development Division, Parks, Planning, and Resources Department.

U.S. Department of Commerce, 1968, Weather Atlas of the United States. 


\section{Appendix:}

Interview Information 
PA Report for Kent National Guard Facility

29

Appendix:

Interview Information

Individuals Interviewed

State Environmental Officer

Washington Army National Guard

Camp Murray

Tacoma, Washington

Staff

Kent National Guard Facility

Kent, Washington

Argonne Investigators

Peter Ketels

(303) $986-1140$

Pradeep Aggarwal

(708) 252-7053 

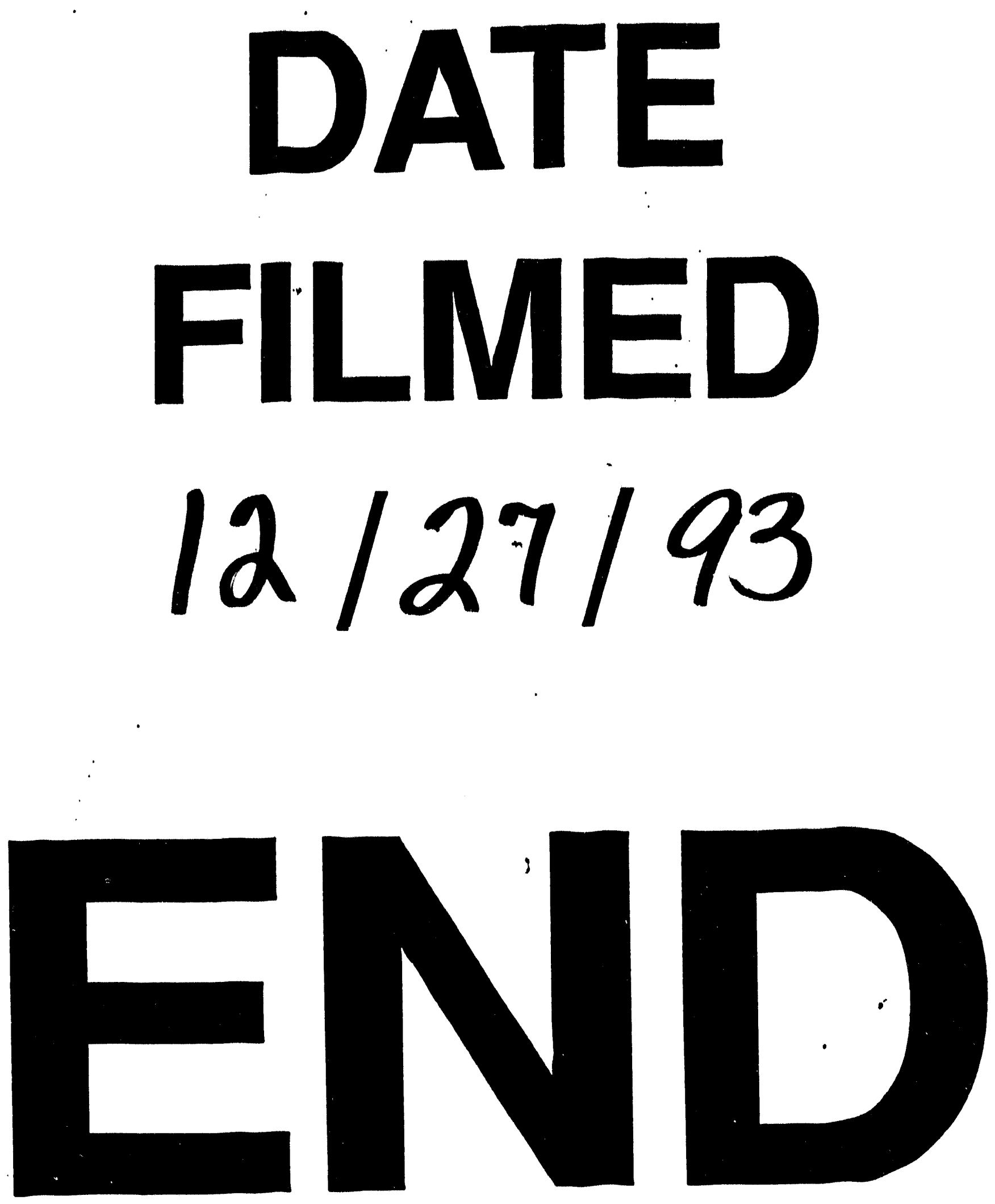
